\title{
Hijab Syar'i: Religious Expression in the Phenomenon of Hijrah among the MuslimFemale Students
}

\author{
M Muhammadun ${ }^{1}$, M A R Bedong ${ }^{2}$, H Said $^{3}$ \\ Institut Agama Islam Negeri (IAIN) Parepare, Jawa Timur, Indonesia 1,2,3

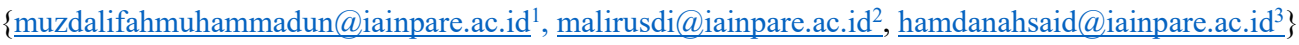

\begin{abstract}
Every Muslim ideally has a goal to practice Islamic laws through their religious expression. The increasing awareness of students in closing their aurat as part of their religious orders showed this fact. This paper examines the phenomena of hijrah among the millennial students in which they are committed to wear hijab syar'i. Hijab syar' $i$ is a term or an icon to distinguish the use of non-syari or non-Islamic hijab. Hijab is a long dress that covers the entire body except for the face, hands, and feet, usually worn by Muslim women.Every student has his or her own opinions and views about this dress. Some of them considered that'hijab is hijab' and there is no need to add syar'iterm in it. Others said that hijabsyar'iis very different from the understanding of hijab clothing in general. This group found that wearing a hijab for fashion is the same as not wearing a hijab. This study will use two analyzes in examining this phenomenon, i.e. intrinsic and extrinsic. The first covers all things from within a student, while the later refers to factors outside of the student. The result showed that the phenomenon of hijrah builds awareness to the female students of self-actualization model in expressing their religious perfectness in an increasingly modernized world.
\end{abstract}

Keywords: Hijab Syar'i, Religious Expression, Hijrah

\section{Introduction}

One study by Fedwa El Guindi, an Egyptian Professor of Anthropology, traced the history of a veil by attending and participating in a movement in some Islamic countries in the East. The research found that hijab is a phenomenon that is rich and full of meaning [1]. Hijab serves as a language that conveys social and cultural messages. For Christians, the veil became a significant symbol of the ideological fundamentals. For the Catholics in particular, hijab is a part of femaleness and piety [2], and for some Islamic movements, the headscarf is a symbol of identity and resistance.

Indeed, one of the goals for Muslim women to wear hijab is to cover their aurat. Allah's command to close aurat is found in QS. Thaha (20): 117-118, in which Adam was reminded of that if he were driven out of heaven because of Satan, he would undoubtedly struggle in the world to find clothing, food, and shelter [3], [4]. God had created this encouragement as part of human instincts. This is seemingly the reason that even primitive humans always cover up their aurats. The verse also implied that covering aurats needs no difficult effort because it can be done by any available materials, even a leaf (as long as it can cover it) [5].

Hijab is a global trend now, including in Indonesia. If the headscarf was identical to the female students' clothes in Islamic boarding schools, it now has become very popular and accessible. In public spaces, anywhere, we can see and meet Muslim women who wear headscarves. Hijab or jilbab is commonly accessible and popular from small children to grandmothers, from small villages to big cities. Even the veil is now an identification of a class. The headscarf began to be worn by the wives of the officials, including celebrities, although often limited to the month of Ramadhan. 
Hijrah is a consistent improvement wherein each individual is required to complete God's direction and to avoid His preclusions persistently [6]. The ascent of the millennial age, particularly students at university, to do hijrah shows up in their demeanors and conducts in deciphering the importance of hijab. Since then, the community of hijab syar'i emerged even though some did not use a specific name. They reinforce one another in various forms and different activities, such as hopping in social administration, figuring out how to pursue the Qur'an, taking part in religious dialogues, and typically conducting a monthly religious gathering by inviting a religious teacher.

This paper examines the phenomena of hijrah among the millennial students in which they are committed to wearing hijab syar'i. Hijab syar'i is a term or an icon to distinguish the use of non-syari or non-Islamic hijab. Hijab is a long dress that covers the entire body except for the face, hands, and feet, usually worn by Muslim women. Internal and external factors behind the wear of hijab will be studied carefully.

\section{Method}

In total, ten hijabis students were interviewed based on a snowball technique. All participants were students from different faculties at IAIN Parepare. Individual semi-structured interviews were conducted between 30-60 minutes over the phone [3]. The interviews were audio-recorded. At the transcription stage, participants' names were replaced with pseudonyms, and all identifying details were removed.

The interviews explored two of the following topics: 1. Informants' understanding of Islam and its influence on their lives; 2. whether they considered themselves as spiritual. Both topics are divided into four sub-topics, including heir understanding of Muslimah clothing; their opinions on religious values as a Muslim woman; their attitudes and behaviors; and reasons for wearing hijab syar'i. Particular considerations were given to sensitive issues for in-depth discussions while ensuring that participants remained within the boundaries of what they felt comfortable sharing [7].

A qualitative study is led and guided by thematic analysis, which Howitt and Cramer [8] describe it as theme identification through data analysis. Braun and Clarke's [9] said that this model is utilized to analyze data by identifying overarching themes and sub-themes and defining each theme appropriately. This was achieved through reading the transcripts, highlighting reoccurring and meaningful data as initial themes, then revisiting them to cluster and narrow down to most significant findings, and finally renaming themes and sub-themes. Braun and Clarke [9]suggested themes in the data set reveal meanings or patterns, which the study aimed to shed light on.

\section{Result and Discussion}

Four core themes were identified through thematic analysis, all of which denote female student's experiences and opinions about hijab syar'i at IAIN Parepare. These include informants' understanding of Muslimah clothing, their religious values, attitudes and behaviors, and their reasons for wearing hijab syar'i.

\section{Understanding Muslimah Clothing}

Students' perceptions of wearing a hijab are quite diverse. They reflected their understanding of dressing with what they wear. The answers can be classified into two: students know the meaning of hijab according to what is written in the Qur'an and hadiths and students who know a little about hijab.

All informants stated that wearing a hijab is mandatory for every Muslim woman who had come into puberty. The understanding of informants about the characteristics of the hijab syar' $i$ can be seen in the following quotes:

Extract 1

"Hijab syar' $i$ isa hijab that covers the aurats that include not only the head (hair), but also the chests also. Moreover, in my opinion, hijab syar'i mean wearing a veil at least in length until the elbows that automatically covers the chest." 
Extract 2

"Muslimah clothing is clothing that reflects and characterizes Muslim women who cover the body, except the palms and faces."

From the answers above, it appears that the obligation to close the aurats for Muslim women is not negotiable. It additionally demonstrates that in practice all informants comprehended the guidelines written in the Qur'an and the Sunnah.

\section{Extract3}

"Everybody has an alternate perspective on hijab; some stated that she has the responsibility to cover her private parts by veiling to the elbows, bottom, and knees. In this way, in my opinion, let them unreservedly evaluate what the hijab is; the most important thing is a readiness to cover the private parts, and later they will acknowledge themselves about hijab syar'i."

Hijab syar' $i$ is undoubtedly very different from hijab gaul. Even so, it is not appropriate to say that those who wear non-syar'i hijab are lack of faith. A Muslim woman wearing a hijab has the responsibility to advise her friends to wear a hijab. Some interviewees argue that every Muslim woman must respect each other. Furthermore, hijabis must not impose or even denounce on their sisters because of her non-syar'i clothes.

\section{Religious Values: Hijab as Identity-Consolidating Performance}

Several participants described that adopting a hijab makes their Muslim identity visible. One interviewee explained how her decision to adopt a hijab was prompted (in part, at least) by the desire to let others know she was a devout Muslim.

Some reported that making one's Muslim identity visible through wearing the hijab had an implication for how her behavior will be judged. For example, one explained that people expected the hijab-wearing woman to be 'perfect':

Extract 4

"When I stop and look at the mirror, I think 'what do people see?' They see a holy, holy person because the hijab is often associated with a nun and nuns are really, really good people [ ], and sometimes I have had to say to people, 'But I am not perfect. You have got this image of me that I am perfect.' One misconception is that you put the hijab on when you have reached perfection, but no, that is not true, we will never reach perfection, we are just trying to better ourselves."

\section{Extract 5}

"I did feel that I represent Islam, so I did feel like I was presenting something, and I felt like that was my belief, and that is who I am, and that is why I started wearing, like why I started covering. So for me, it was, that is what made me stop and think. Maybe if I had not covered and I had come to Uni, and then there were so many decisions - do I cover? Do I do this? Do I go? It would have been a lot harder."

Again, there is a sense in which she believed her visibility as a Muslim rendered her accountable as a female Muslim, which in turn encouraged an identity performance that allowed her to realize her Muslim identity better.

\section{Attitudes and Behaviors}

We saw a two-way connection between identity and practice in this chapter. If wearing a hijab can be a performative act for communicating identity, the information reviewed here demonstrated that respondents reflected on this visibility and their accountability as Muslims and how this motivated a performance of identity in which they tried to realize identity-related virtues.

Some of the interviewees said that by wearing a hijab, especially a hijab syar'i we should have self-control for our everyday life. Here again, the interviewee reported that her wearing hijab has facilitated her subsequent enactment of the Islamic injunction. Indeed, she continued that it was partly 
in order to manage others' expectations of herself and her behaviors that she had adopted hijab in her everyday life: as she put it, 'if I call myself a female Muslim I should look like one because it stopped others asking 'what kind of Muslim are you?'

Extract 6

"I wore a hijab since I was young. Until now, the hijab that I used was very protective of my relationships. When I leave the house, I feel uncomfortable if I don't wear it, even if it's only on the porch or just sweeping the yard."

\section{Extract 7}

"My behavior has been maintained since I wore hijab syar'i, the way I get along with friends and people become more nurtured."

Again, this reflected that a psychological significance of one's visibility and accountability (as a Muslim woman) has motivated an identity performance that realizes identity-related ideals ('you don't want to be one of those people who put other people off'). It is also noteworthy to mention that the two interviewees' contributions (in this group interview) supported this account.

What emerges slowly from the assessment of where the female students take power from is that Islam is predominantly rooted in their life philosophy. Everyone defined her faith as 'a manner of life' by governing every aspect of their decision-making, behaviors, giving them a more significant objective and relationship to the divine.

\section{The Underlying Reason for Wearing HijabSyar'i}

The amount of IAIN Parepare female students wearing hijab syar'i, of course, is influenced by many variables. There are two primary variables, namely intrinsic and extrinsic factors, based on the author's interview outcomes. Intrinsic variables come from within, referring to the level of comprehension and consciousness. Extrinsic variables come from the setting, teacher encouragement, trends/fashions, and family factors. Of the five variables, environmental variables are the most dominant factor based on the interview outcomes. One interviewee said:

\section{Extract 7}

"Alhamdulillah, after I wear hijab syar'i, I have friends who always invite me in kindness, for example, by inviting me to learn religious knowledge, advising me if I eat sweets while standing, inviting me to memorize the Quran, and correcting my recitation either."

\section{Extract 8}

"The first reason I used hijab syar' $i$ was because of the commands of Allah and the prophet. Secondly, my mother has been wearing a hijab for a long time ago. Thirdly, it is part of my responsibilities as students or santri who ever lived in an Islamic boarding school (pesantren). Lastly, the campus where I am currently studying offers an excellent opportunity for me to become a better person in the future."

In addition to the encouragement from the campus environment, some started wearing hijab because of their family background, so that they wear hijab from an early age. One reason is that the parent of the student (the hijabis) are respected religious figures.

\section{Hijrah and Hijab}

At the point when a person chooses to move, leave her past, and commit to being a better individual, her design style likewise changes. What was initially been open became closed, what initially tight became loose, following the religious provisions they believe in. The informants,i.e. female students of IAIN Parepare, are generally on the same opinion on women as a source of immorality.

Discourse on Hijrah is grasped by female students, mainly through their appearances, by altering their identity. The first thing they did was to wear hijab syar'i when they decided to do Hijrah. 
Previously, they just wore clothing covering their bodies without knowing shari'a laws. Now, they replaced it by wearing clothing complete of compulsory demands, which include covering all bodies with untransparent, long, and wide veils dangling down under the abdomen, loosing without hugging curves, not imitating men's clothings (pants), not functioning as jewelry, not resembling the clothes of the infidel women, not spraying perfume, and not attracting others' attention.

The next consequence is to make God's rules as a form of physical and spiritual obedience and leave everything forbidden [10]. One of them is that women who do Hijrah must obey the provisions that regulate the opportunity for Muslim women to appear in public, both in the real and online worlds.

As explained earlier, experimentation is ideal for addressing many aspects of identity performance [2]. However, the social identity concept of performance implies that individuals have a reflexive awareness of how others could view them and how they orient to others' perceptions of them [11]. The analysis offered here showed that there is much to be gained through considering such understanding.

Three informants attempted to get out of a dominant discourse that females as hijabis should maintain 'syar' $i$ ' attitudes. They agreed to build a women's discourse that hijrah enables them to freely do activities while carrying the hijab syar' $i$ without being burdened and shadowed by religious dogma. Wearing hijab syar'i is not a barrier to do many activities and not something to be feared. The experience of the hijrah process is proof of loving God's rules, i.e. keep wearing clothes that are stated in any situation as a form of commitment to hijrah.

Furthermore, some students expressed their willingness to fight the dominant discourse that a woman of hijrah is necessarily religious and obedient due to her practice of syariah. They wanted to create their own identity by undermining the dominant view of female students who wear hijab syar'i by not blaming hijab syar' $i$ because for them clothes and morals are two different things.

Hijab syar'i dressing is not a measure of whether a female Muslim is loyal or not. On the other side, this statement is emblematic of the habitus concept of Pierre Bourdieu that even though she was doing hijrah with a syar' $i$ appearance, it is not simple to adjust her habits before hijrah was achieved. The self-identity of a female student wearing hijab syar'i is built on the assumption that a Muslim woman is free to do all of her activities without bearing the burden of religious beliefs. They attempted to oppose the dominant discourse that females who are in hijrah and wearing hijab syar'i are idealized females and the symbols of religious values and goodness. The two informants agreed that, in their first in hijrah, they will not associate morality and conducts with syar' $i$ appearances.

Two significant themes, i.e.the informants' understanding of Islam and its influence on their lives and whether they consider themselves as spiritual, showed that religious awareness in wearing hijab syar'i is that it is one form of obedience to God. In addition to other commands, it showed us that religious awareness among students, especially female students, will help them control their behaviors from what is prohibited by religion.

\section{Conclusion}

Hijab is not only a piece of cloth that covers your head; it reflects individuals' minds. Hijab is not limited to head covering: conducting life unpretentiously is also significant in fulfilling the requirements of hijab. Modest behavior is a fundamental aspect of the hijab. Much statement argued that hijab sets a boundary between men and women or that it helps them avoid premarital or illegal relationships, which are not permissible in Islam. Women need to wear a hijab because it keeps society pure in many ways. However, more research on such performances is needed. For example, the informants established an identity of resistance to fight pressure on their identity from any actor or condition. Therefore, without any shadow of religious values, they can state their position as hijrah women while wearing hijab syar'i.

\section{References}

[1] N. Hopkins and R. M. Greenwood, "Hijab, visibility and the performance of identity Hijab , visibility and the performance of identity," no. August 2013, 2017. 
[2] K. Kale and R. Hart, "Faith Will Move Mountains: A Qualitative Exploration of Veiled British Muslim Women 's Experiences in the UK Post-Brexit," no. August 2018, 2017.

[3] M. Saprudin, M. Amali, and S. Narulita, "Motivasi pemakaian jilbab mahasiswi Islam universitas negeri Jakarta,” J. Stud. Al-Qur'an, vol. 12, no. 2, pp. 182-193, 2016.

[4] U. Sidiq, "Diskursus Makna Jilbab Dalam Surat Al-Ahzab Ayat 59 Menurut Ibnu Kathir dan M. Quraish Shihab," Kodifikasia, vol. 6, no. 1, pp. 1-26, 2010.

[5] M. Q. Shihab, Wawasan al-Quran. Bandung: Mizan Pustaka, 2007.

[6] A. A. Rita, "Assertion of Wearing Hijab in the Community: an Analysis," Am. Sci. Res. J. Eng. Technol. Sci., vol. 29, no. 1, pp. 340-347, 2017.

[7] C. Willig, Introducing Qualitative Research In Psychology. London: McGraw-Hill Education, 2013.

[8] D. Howitt and D.Cramer, Introduction To Research Methods In Psychology. Harlow: Pearson Education Limited, 2011.

[9] V. Braun, Successful qualitative research: A practical guide for beginners. London: Sage Publication, 2013.

[10] D. Zwick and C. Chelariu, "Mobilizing the hijab: Islamic identity negotiation in the context of a matchmaking website," J. Consum. Behav., vol. 5, no. 4, pp. 380-395, 2006.

[11] K. Rudy, "Ethics, reproduction, utopia: Gender and childbearing in Woman on the Edge of Time and The Left Hand of Darkness," NWSA J., vol. 9, no. 1, p. 24, 1997. 